\title{
Some properties of sustainable concrete containing two environmental wastes
}

\author{
Wasan Khalil ${ }^{1, *}$, and Nazar Al Obeidy ${ }^{2}$ \\ ${ }^{1}$ Building and Construction Engineering Department, University of Technology, Baghdad, Iraq \\ ${ }^{2}$ National Center for Construction Laboratories, Baghdad, Iraq
}

\begin{abstract}
This investigation includes the use of $15 \%$ of glass wastes as a partial substitution to cement in combination with plastic wastes as volumetric replacement to natural coarse aggregate to produce sustainable concrete. Different volumetric replacements of plastic waste to natural coarse aggregate (25\%, $50 \%, 75 \%$, and $100 \%$ ) were used in concrete containing $15 \%$ glass powder as a replacement by weight of cement. Generally, the results show that the inclusion of $15 \%$ glass powder improves the compressive strength, splitting tensile strength and flexural strength by about $13.3 \%, 36.3 \%$, and $34.7 \%$ respectively at 60 day age in comparison with reference concrete without wastes, also the results show a decrease in water absorption and an increase in dry density. The inclusion of plastic waste aggregate in the presence of $15 \%$ glass powder leads to a decrease in the compressive strength, flexural strength, splitting tensile strength, dry density, ultrasonic pulse velocity, and thermal conductivity. The percentage reductions are $59.8 \%, 46.3 \%$, $43.6 \%, 20.5 \%, 28.6 \%$, and $54.4 \%$ respectively for concrete specimens that including $100 \%$ plastic waste coarse aggregate in comparison with concrete specimens without plastic waste aggregate.
\end{abstract}

\section{Introduction}

The concept of sustainability is now very important in the construction industry. It is known as ensuring the complacency of the present requirements without permuting the ability of future generation ${ }^{[1]}$. Concrete is one of the main materials used in construction activities in the world. Annually the production of concrete all over the world is about twelve billion tons that consume nearly 1.6 billion tons of Portland cement, ten billion tons of rocks and one billion ton of water ${ }^{[2]}$. The production of one ton of Portland cement creates about 1 tons of $\mathrm{CO}_{2}$ gas that causes environmental pollution. It is clear that the concrete industry significantly affects the environment. It is not reasonable to confine the use of concrete, but there are several manners to reduce its environmental influence ${ }^{[2,3]}$. Huge quantities and types of glass waste and plastic are generated all over the world due to the large use of these products. Most of these solid wastes have been buried in landfill sites; this land filling of wastes is unfavorable because these wastes are non-biodegradable, which makes this process environmentally less friendly. So, it is required to start a new solution for sustainable development. One of the best solutions of sustainable solid waste management is the ability to Reduce, Reuse and Recycle of these wastes to the maximum as possible ${ }^{[4]}$. To produce eco-friendly concrete, some researchers studied the replacement of cement by other materials (supplementary cementitious materials). The chemical composition of these materials mainly contains reactive silica that reacts with $\mathrm{Ca}(\mathrm{OH})_{2}$ (one of the hydration products of cement) to produce additional gel, which improves some properties of concrete ${ }^{[5,6]}$. Some types of these materials are byproducts from industry. In addition, there are natural materials, namely natural pozzolans such as metkaolin that is produced from kaolin clay after firing this clay to a temperature between $600{ }^{\circ} \mathrm{C}-800^{\circ} \mathrm{C}{ }^{[7,8]}$.

In Iraq the by-product supplementary cementitious materials such as, silica fume, fly ash, etc. are not available, while metkaolin as a natural Pozzolan can be produced from kaolin clay, which exists in large deposits in Iraq. However, the use of metkaolin as a replacement to cement consumes the kaolin clay from environment; in addition, it consumes a large amount of energy during the burning process that makes this material less sustainable. Therefore, it is very important to find alternative sustainable material that can be used as a replacement to cement in concrete industry. The use of different waste materials (recyclable Portland cement concrete, plastic, brick and others) as aggregate in concrete industry can consume huge quantities of these materials. In this case, the problems of consume aggregate in construction sites, and environmental pollution problems can be solved. The inclusion of plastic waste as aggregate in concrete can significantly improve some properties of concrete, because plastic has low thermal conductivity, low density, good abrasion resistance and high toughness.

The aim of this study is to investigate the effect of using

\footnotetext{
* Corresponding author: wasan1959@yahoo.com
} 
glass waste powder and plastic waste, on some properties of concrete.

\section{Research significance}

Research significance can be summarized as follows:

* Recycling of glass and plastic wastes (collection, washing, and preparing) and classifying them based on ASTM.

* Investigating the properties of concrete containing the $15 \%$ of glass waste powder as a replacement to cement by weight and different percentages of crushed plastic as replacement by volume of natural coarse aggregate.

\section{Experimental program}

\subsection{Materials}

* Ordinary Portland cement type (1) was used in this investigation. Test results show that the taken cement has satisfied the Iraqi Standard No. 5/1984.

* Normal weight natural sand with maximum size of $4.75 \mathrm{~mm}$ was used. The results demonstrate that the gradation of the sand, $\mathrm{SO}_{3}$ content and physical properties conform to the Iraqi Standard No. 45/1980.

* Natural crushed gravel with maximum size of $14 \mathrm{~mm}$ was used in this study. The grading and sulphate content of the coarse aggregate conform to the Iraqi Specifications No. 45/1984.

* Potable water from the water supply network was used for mixing and curing of concrete.

* High, range, water reducer admixture with a commercial mark of GLENIUM. 54.0 was utilized. It is compatible with ASTM C494 type F.

* Glass powder waste and plastic waste aggregate were used after preparation and classification.

\subsection{Preparation of glass waste}

White glass waste was collected, washed and broken into small pieces as shown in Figure (1-a). The glass was then crushed by using a crusher type Retsch shown in Figure (1-b). The particle size of the glass waste after the crushing process varied from $0-0.5 \mathrm{~mm}$ as shown in Figure (1-c). After that it was grinded by a grinder type Retsch shown in Figure (1-d). The grinding was carried out at different time periods (1, 5, 10, and 15 minutes). Glass powder sample after grinding process is shown in Figure (1-e). Finally, the glass powder was screened on sieve No.200 (75 microns), as shown in Figure (1-f).

\subsection{Experimental test on glass powder}

The following tests were conducted on the prepared glass powder to make sure that this powder had properties which conform to the properties of natural pozzolans according to ASTM C618; all results are illustrated in Table (1):

-Fineness test was carried out on the glass powder after each grinding period $(1,5,10$, and 15 minutes) in accordance with ASTM C204.
-Strength Activity Index (S.A.I.) test at 7 and 28 day age was conducted according to ASTM C 311.

-The Remaining on the Sieve 45 Microns (No. 325) test was carried out based on ASTM C 430.

-The Chemical Analysis (Quantitative and Qualitative) was conducted using X-ray diffraction by EDX-7000 device ${ }^{[9]}$.

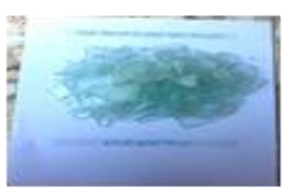

a
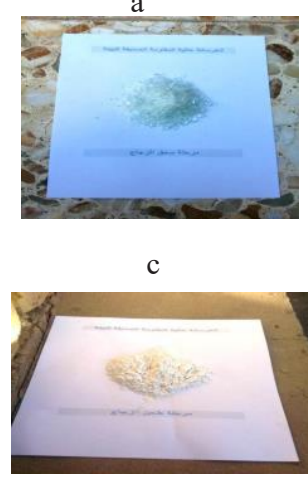

$\mathrm{e}$

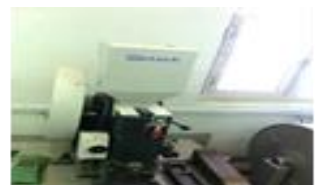

b

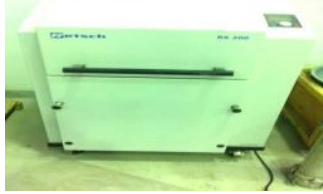

d

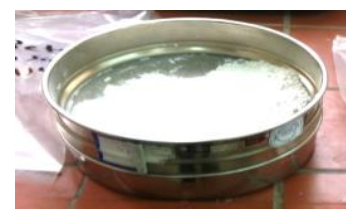

f
Fig. 1. Preparation of Glass Waste Powder

Table 1. Properties of Glass Powder

\begin{tabular}{|c|c|c|}
\hline $\begin{array}{c}\text { Some of chemical } \\
\text { composition of components }\end{array}$ & Value $(\%)$ & $\begin{array}{l}\text { Requirements of } \\
\text { ASTM C- } \\
\text { 618Specifications } \\
\text { Class N }\end{array}$ \\
\hline $\mathrm{SiO}_{2}$ & 84.862 & \multirow{3}{*}{$\geq 70$} \\
\hline $\mathrm{Al}_{2} \mathrm{O}_{3}$ & 5.529 & \\
\hline $\mathrm{Fe}_{2} \mathrm{O}_{3}$ & 0.311 & \\
\hline $\mathrm{CaO}$ & 7.934 & --- \\
\hline $\mathrm{SO}_{3}$ & 0.036 & $\leq 4$ \\
\hline $\mathrm{K}_{2} \mathrm{O}$ & 1.251 & --- \\
\hline $\mathrm{TiO}_{2}$ & 0.037 & --- \\
\hline $\mathrm{ZrO}_{2}$ & 0.011 & --- \\
\hline $\mathrm{Cr}_{2} \mathrm{O}_{3}$ & 0.010 & --- \\
\hline $\mathrm{SrO}$ & 0.008 & --- \\
\hline $\begin{array}{c}\text { Retained on a Sieve } 45 \mu \mathrm{m} \\
(\%)\end{array}$ & 9.88 & $\leq 34$ \\
\hline $\begin{array}{l}\text { Fineness(Blain Method) } \\
\text { After } 10 \text { Minutes Grinding } \\
\left(\mathrm{cm}^{2} / \mathrm{gm}\right)\end{array}$ & 7340 & --- \\
\hline Specific Gravity & 2.265 & --- \\
\hline L.O.I (\%) Loss on Ignition & 0.41 & $\leq 10$ \\
\hline $\begin{array}{l}\text { Strength Activity } \\
\text { Index }{ }^{* 2}(\%) \\
7 \text { days } \\
28 \text { day } \\
\end{array}$ & $\begin{array}{l}80.2 \\
83.0\end{array}$ & $\begin{array}{l}\geq 75 \\
\geq 75\end{array}$ \\
\hline
\end{tabular}

\subsection{Preparation of plastic waste}

Vegetable containers were collected, washed with water, and then crushed to small pieces by a crusher in Bub Al - 
Sham region in Baghdad. The crushed plastic waste was sieve on standard sieves then prepared with gradation that agrees with Iraqi Standard No.45/1980 and corresponding to natural aggregate used in this study, as shown Figure (2).

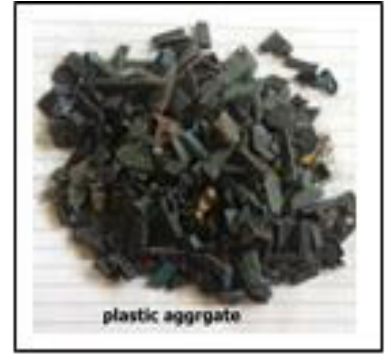

a. Plastic Waste Aggregate.

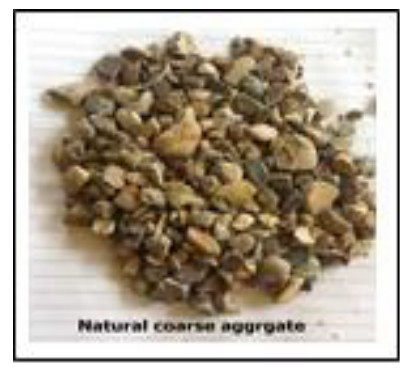

b. Natural Crushed Aggregate
Fig. 2. Coarse Aggregate Used in this Investigation.

\subsection{Experimental test on plastic waste}

\subsubsection{Fourier Transforms Infrared Spectroscopy Analysis}

Fourier transforms infrared spectroscopy (FTIR) ${ }^{[10]}$ analysis is a subset of spectroscopy that deals with the infrared region of the electromagnetic spectrum. It can be used to identify compounds or investigate the composition of a material. Figure (3) shows the analysis of plastic waste used in this study. By observing the results of the analysis and comparing them with the results of the standard plastic analysis by FTIR for each of polyethylene, polypropylene, polystyrene, and polyethylene chloride, the test result shows that the plastic is closer to the polyethylene.

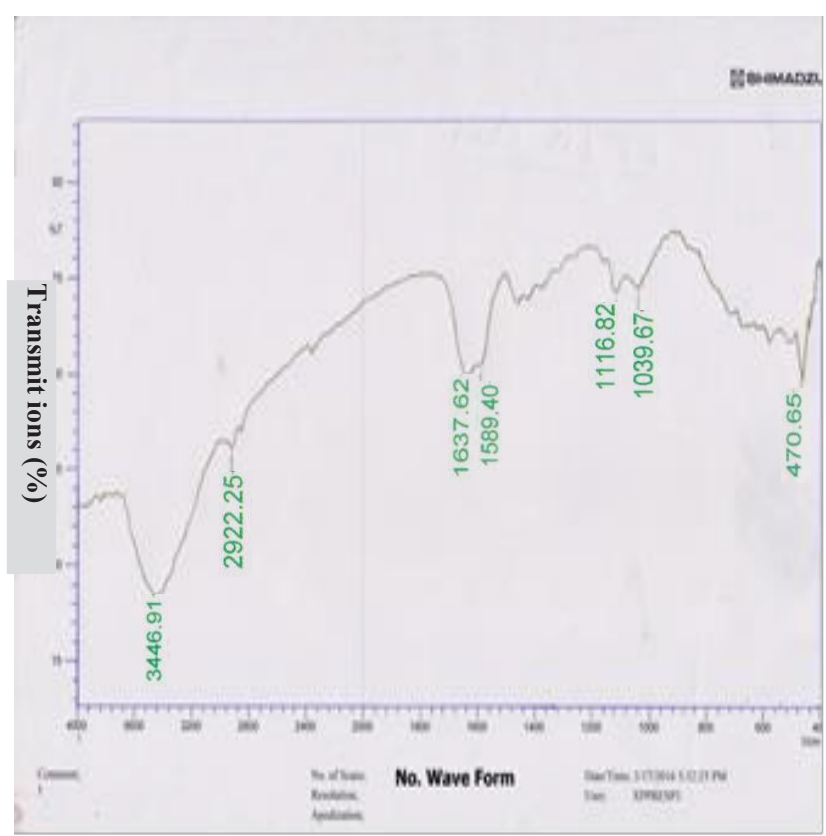

Fig. 3. FTIR Analysis of Plastic Waste

\subsubsection{Sieve analysis}

The coarse plastic aggregate was prepared to satisfy the requirements of IQS 45/1980 for natural coarse aggregate with max size of $14 \mathrm{~mm}$. The grading of plastic waste aggregate used in this investigation is shown in Table (2). It is the same as that for crushed natural coarse aggregate used in this study.

Table 2. Grading of Plastic Waste Aggregate

\begin{tabular}{|c|c|c|}
\hline $\begin{array}{c}\text { Sieve size (mm) according } \\
\text { to Iraqi standard }\end{array}$ & Passing (\%) & $\begin{array}{c}\text { Limits of Iraqi } \\
\text { Standard No. 45 } \\
/ 1980(5-14) \mathrm{mm}\end{array}$ \\
\hline 14 & 100 & $90-100$ \\
\hline 10 & 70 & $50-85$ \\
\hline 5 & 2 & $0-10$ \\
\hline
\end{tabular}

- Density test was carried out based on ASTM D792 [11].

- Flexural Strength test was conducted based on ASTM D790 [12].

- Compressive Strength test based on ASTM D695 [13] was carried out.

- Tensile Strength test was carried out according to ASTM D 638 ${ }^{[14]}$.

- Thermal conductivity was carried out using Lee's Disc Method [15]

- Impact Test was carried out based on ISO 179[16]

All test results are illustrated in Table (3).

According to the properties of plastic waste in Table (3) and the Figure 3 of FTIR analysis, the plastic waste used in this investigation can be classified as polyethylene plastic. Generally polyethylene plastic is classified in to three types, low density (0.910-0.925 gm/ cm3), medium density (0.926-0.94 gm/cm3), and high density (0.941$0.959 \mathrm{gm} / \mathrm{cm} 3$ ) according to ASTM D3350 [17], so plastic waste used in this investigation is high density polyethylene (HDPE).

Table 3. Physical Properties of HDPE Plastic Waste Used in this Investigation

\begin{tabular}{|c|c|c|c|}
\hline Item & Property & Value & $\begin{array}{c}\text { ASTM } \\
\text { Specifications }\end{array}$ \\
\hline 1 & Density $\left(\mathrm{gm} / \mathrm{cm}^{3}\right)$ & 0.949 & ASTM D792 ${ }^{[11]}$ \\
\hline 2 & $\begin{array}{c}\text { Flexural Strength } \\
\left(\mathrm{N} / \mathrm{mm}^{2}\right)\end{array}$ & 878.34 & ASTM D 790 $0^{[12]}$ \\
\hline 3 & $\begin{array}{c}\text { Compressive Strength } \\
\left(\mathrm{N} / \mathrm{mm}^{2}\right)\end{array}$ & 26.46 & ASTM D638 ${ }^{[14]}$ \\
\hline 5 & $\begin{array}{c}\text { Tensile Strength } \\
\left(\mathrm{N} / \mathrm{mm}^{2}\right)\end{array}$ & 7.7 & ASTM D638 ${ }^{[14]}$ \\
\hline 6 & $\begin{array}{c}\text { Thermal of } \\
\text { Conductivity } \\
\left(\mathrm{W} / \mathrm{m}^{2} \mathrm{~K}\right)\end{array}$ & 0.118 & $\begin{array}{c}\text { Lee's Disc } \\
\text { Method }\end{array}$ \\
\hline 7 & $\begin{array}{c}\text { Impact Charpy } \\
\left(\mathrm{kJ} / \mathrm{m}^{2}\right)\end{array}$ & 16.27 & ISO-179 ${ }^{[16]}$ \\
\hline
\end{tabular}




\subsection{Selection of mix proportion for the reference concrete}

Reference concrete mix was designed according to British Method for concrete mix design [18], to get concrete compressive, strength at least of $40 \mathrm{MPa}$ at 28 day age without any additives. The mix of cement: sand: crushed coarse aggregate is in the ratio 1:1.4:1.8 by weight with cement content of $500 \mathrm{~kg} / \mathrm{m}^{3}$, slump test value of $100 \pm 5.0 \mathrm{~mm}$ and $\mathrm{w} / \mathrm{c}$ ratio of 0.42 . Many trial mixtures were conducted to choose the optimum dose of high, range water reducer admixture (HRWRA). The w/c ratio was modified to give the constant workability of the reference mixture (slump test value of $10.0 \pm 5.0 \mathrm{~mm}$ ). The major task of utilizing HRWRA is to decrease the amount of water mix, whereas keeping the constant workability of reference mixture. The details of the designed reference concrete mix containing various dosages of superplasticizer (HRWRA) are given in Table (4). The experimental results in this study mentioned that the optimum dose of high range water reducing admixture is $1.5 \mathrm{~L} / 10.0 \mathrm{~kg}$ of cement that gives reduction in water by about $35.71 \%$ and maximum compressive, strength of $59.6 \mathrm{MPa}$ at 28 day age.

Table 4. Experimental Concrete Mixtures Containing Different Dosage of Superplasticizer

\begin{tabular}{|c|c|c|c|c|c|c|}
\hline \multirow{2}{*}{$\begin{array}{c}\text { Mix } \\
\text { proportio } \\
\text { n by } \\
\text { weight }\end{array}$} & \multirow{2}{*}{$\begin{array}{c}\text { Dosage } \\
\text { of } \\
\text { HRWR } \\
\text { (liter } / 10 \\
0 \mathrm{~kg} \text { of } \\
\text { cement ) }\end{array}$} & \multirow{2}{*}{$\begin{array}{l}\mathrm{w} / \mathrm{c} \\
\text { ratio }\end{array}$} & \multirow{2}{*}{$\begin{array}{c}\text { Slum } \\
\underset{(\mathrm{mm})}{\mathrm{m}}\end{array}$} & \multirow{2}{*}{$\begin{array}{l}\text { Water } \\
\text { reduct } \\
\text { ion } \\
(\%)\end{array}$} & \multicolumn{2}{|c|}{$\begin{array}{c}\text { Compressive } \\
\text { strength } \\
(\mathrm{MPa})\end{array}$} \\
\hline & & & & & $\begin{array}{c}7 \\
\text { days }\end{array}$ & $\begin{array}{l}28 \\
\text { day }\end{array}$ \\
\hline $\begin{array}{c}1: 1.4: 1.8 \\
\text { (cement } \\
\text { :sand }\end{array}$ & 0 & 0.42 & 95 & --- & 28.9 & $\begin{array}{c}40.4 \\
6\end{array}$ \\
\hline $\begin{array}{c}\text { :gravel)ce } \\
\text { ment }\end{array}$ & 0.5 & 0.36 & 102 & 14.28 & 38.1 & 48.6 \\
\hline $500 \mathrm{~kg} / \mathrm{m}^{3}$ & 1.0 & 0.30 & 104 & 28.57 & 41.5 & 53.8 \\
\hline $\begin{array}{c}\mathrm{w} / \mathrm{c}=0.27, \\
\text { HRWRA } \\
=1.5\end{array}$ & 1.5 & 0.27 & 102 & 35.71 & 47.7 & 59.6 \\
\hline $\begin{array}{l}\text { Liter/100 } \\
\mathrm{kg}\end{array}$ & 2.0 & 0.28 & 102 & 33.34 & 43.2 & 55.2 \\
\hline
\end{tabular}

\subsection{Concrete mixes}

After the selection of optimum dosage of HRWRA, several concrete mixes were prepared. Concrete mixes prepared in this investigation are shown in Table (5).

\subsection{Mixing, preparation, and curing of concrete specimens}

The processes for all concrete mixes were performed in an electrical rotary vessel mixer of $0.1 \mathrm{~m}^{3}$ capacity according to ASTM C 192/C192M. After removing the concrete specimens from molds, all the specimens were completely immersed in water storage tank containing water mixed with $3 \mathrm{gm} /$ litter of calcium hydroxide according to ASTM C511. Concrete specimens were cured till the time of test.

Table 5. Details of Concrete Mixes Used in this Investigation

\begin{tabular}{|c|c|c|c|c|c|}
\hline $\begin{array}{c}\text { Grou } \\
\mathrm{p}\end{array}$ & $\begin{array}{l}\text { Concrete } \\
\text { mixes }\end{array}$ & $\begin{array}{c}\text { Mix } \\
\text { symbo } \\
1\end{array}$ & $\begin{array}{c}\text { Glass } \\
\text { powd } \\
\text { er } \\
\text { wast } \\
\text { e } \\
\text { conte } \\
\text { nt } \\
(\%)\end{array}$ & $\begin{array}{c}\text { Plasti } \\
\text { c } \\
\text { wast } \\
\text { e } \\
\text { conte } \\
\text { nt } \\
(\%)\end{array}$ & $\begin{array}{l}\text { Age } \\
\text { (day) }\end{array}$ \\
\hline 1 & Reference & G0P0 & 0 & 0 & \multirow{6}{*}{60} \\
\hline 2 & $\begin{array}{c}\text { Concrete } \\
\text { Containing } \\
15 \% \text { Glass } \\
\text { waste Powder } \\
\text { as a } \\
\text { Replacement } \\
\text { to Cement } \\
\text { with natural } \\
\text { coarse } \\
\text { aggregate }\end{array}$ & G15P0 & 15 & 0 & \\
\hline \multirow{4}{*}{3} & \multirow{4}{*}{$\begin{array}{c}\text { Concrete } \\
\text { containing } \\
15 \% \text { Glass } \\
\text { Powder and } \\
\text { different } \\
\text { percentage of } \\
\text { plastic waste } \\
\text { as volumetric } \\
\text { replacement to } \\
\text { natural coarse } \\
\text { aggregate }\end{array}$} & $\begin{array}{c}\text { G15P2 } \\
5\end{array}$ & 15 & 25 & \\
\hline & & $\begin{array}{c}\text { G15P5 } \\
0\end{array}$ & 15 & 50 & \\
\hline & & $\begin{array}{c}\text { G15P7 } \\
5\end{array}$ & 15 & 75 & \\
\hline & & $\begin{array}{c}\text { G15P1 } \\
00\end{array}$ & 15 & 100 & \\
\hline
\end{tabular}

\subsection{Experimental tests}

The following experimental tests were carried out to study the influence of two wastes on some properties of concrete:

\section{* Slump test based on American Specification ASTM} C143.

* Fresh density test based on American Specification ASTM C 138.

* Oven dry density test based on American Specification ASTM C 642 (using 100×100 mm cube specimens).

* Compressive, strength test based on British Standard 1881 (utilizing $10.0 \mathrm{~mm}$ cube specimens).

* Water absorption test based on American Specification ASTM C642 (using $100 \mathrm{~mm}$ cube specimens). 
* Splitting tensile strength test, based on American Specification ASTM C496 (using $10.0 \times 200 \mathrm{~mm}$ cylindrical specimens).

* Flexural tensile strength test based on American Specification ASTM C78 (utilizing 10.0×10.0×400 mm prism specimens).

* Ultrasonic pulse velocity test according to ASTM C597 (using $100 \mathrm{~mm}$ cube specimens).

* Thermal conductivity test (using cube specimens of $100 \mathrm{~mm})^{[19]}$.

\section{Results and discussion}

\subsection{Properties of concrete containing glass powder waste}

\subsubsection{Fresh concrete properties}

\section{1) Workability}

The experimental results in Table (6) indicate that there is a slight increase in workability with incorporation of $15 \%$ glass powder waste for the same slump compared with reference without wastes, because the glass powder has low water absorption compared with cement. Also it can be seen that there is a slight increase in workability with the increment in plastic waste coarse aggregate in concrete. The improvement in workability of concrete mixes with plastic waste aggregate is attributed to the very low absorbent characteristic of plastic waste in comparison with natural aggregate this correspond with that mentioned by Abduel Majid ${ }^{[20]}$.

\section{2) Fresh density}

The results of fresh density for concrete mixtures containing different percentage of HDPE plastic and $15 \%$ glass powder waste are shown in Table (6) and Figure (4). It can be observed that the use of $15 \%$ glass powder only leads to a decrease in the fresh density of concrete compared with reference (without glass powder) this is due to the low specific gravity of glass powder (2.265) compared with specific gravity of cement (3.15). Also, the increase in plastic waste aggregate content decreases the fresh density. This is attributed to the low density of plastic aggregate $\left(0.949 \mathrm{~kg} / \mathrm{m}^{3}\right)$ compared with that of the natural aggregate $\left(1.715 \mathrm{~kg} / \mathrm{m}^{3}\right)$ in concrete this is compatible with explanation by Kou et al. ${ }^{[21]}$.
Table 6. Effect of Different Contents of Plastic Waste and 15\% Glass Powder Waste on Workability, Fresh, Oven Dry Density, and Water Absorption of Concrete

\begin{tabular}{|c|c|c|c|c|c|}
\hline & $\begin{array}{c}\text { Reducti } \\
\text { on in } \\
\text { water } \\
\text { relative } \\
\text { to the } \\
\text { Symbol of } \\
\text { mixes }\end{array}$ & $\begin{array}{c}\text { Content } \\
\text { of } \\
\text { plastic } \\
\text { waste } \\
\text { (\%) } \\
\text { e } \\
\text { (G0P0) } \\
\text { without } \\
\text { any } \\
\text { wastes } \\
(\%)\end{array}$ & $\begin{array}{c}\text { Fresh } \\
\text { density } \\
\left(\mathrm{kg} / \mathrm{m}^{3}\right)\end{array}$ & $\begin{array}{c}\text { Oven dry } \\
\text { density } \\
\left(\mathrm{kg} . \mathrm{m}^{3}\right)\end{array}$ & $\begin{array}{c}\text { Water } \\
\text { absorption } \\
(\%)\end{array}$ \\
\hline G0P0 & --- & -- & 2496.4 & 2303.4 & 0.73 \\
\hline G15P0 & 0 & 3.7 & 2484.6 & 2341.9 & 0.66 \\
\hline G15P25 & 25 & 6.6 & 2366.7 & 2285.0 & 0.82 \\
\hline G15P50 & 50 & 9.3 & 2275.3 & 2107.1 & 0.91 \\
\hline G15P75 & 75 & 13.1 & 2143.7 & 2023.0 & 0.98 \\
\hline G15P100 & 100 & 17 & 2055.5 & 1862.4 & 1.07 \\
\hline
\end{tabular}

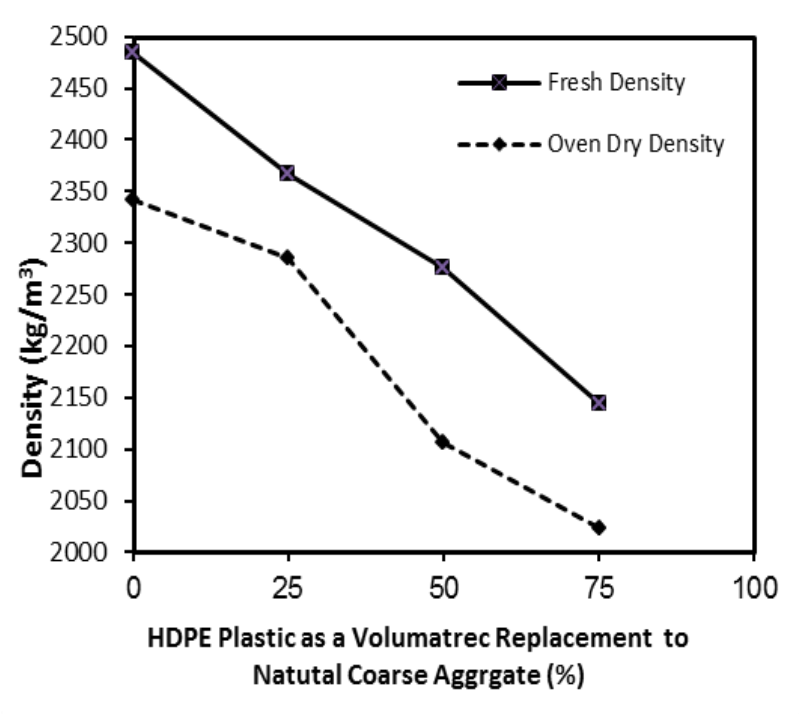

Fig. 4. Fresh and oven dry density of all concrete specimens

\subsubsection{Hardened concrete properties}

\section{1) Oven dry density}

The test results at 60 day age presented in Table (6) and Figure (4) show a slight increase in dry density for specimens containing $15 \%$ glass powder by about $1.671 \%$ relative to reference $(\mathrm{G} 0 \mathrm{P} 0)$. This increment is due to the change of calcium hydroxide ions that have specific gravity of 2.24 to extra gel with specific gravity of 2.3-2.6 [22], that fills the space between particles in the microstructure of concrete. The inclusion of plastic waste aggregate in concrete leads to a significant decrease in the oven dry density of concrete because of the lower density of plastics relative to the density of natural coarse aggregate. The results indicate that concrete specimens containing 100\% HDPE plastic 
waste aggregate and with $15 \%$, glass powder waste has a dry density of $1862.4 \mathrm{~kg} / \mathrm{m}^{3}$

\section{2) Water absorption}

Water absorption of all concrete specimens prepared in this investigation is listed in Table (6). It's clear that the water absorption is decreased for concrete containing $15 \%$ glass powder by $9.8 \%$ in comparison with the reference specimens (without any wastes), this is due to the pozzolanic reaction between the silica in glass powder and calcium hydroxide. This reaction produces extra gel ${ }^{[5]}$, which fills the spaces between particles, as well as segment the continuous capillary pores in the microstructure of concrete, that reduces the permeability consequently and decreases the absorption. The incorporation of plastic waste as coarse aggregate in concrete increases the water absorption with the increase in plastic waste content in concrete specimens. This is because of the shape of plastic aggregate (fluky and elongation), that increases the continuous path between pores and increases porosity. Also the low density of plastic waste leads to unsuitable compaction then more pores are formed.

The water absorption of each concrete mixes is very low and less than $10 \%$. This displays the good quality of all concrete mixes in this investigation ${ }^{[23]}$.

\section{3) Compressive strength}

The effect of $15 \%$ glass powder waste and HDPE Plastic waste coarse aggregate on the compressive, strength of concrete is explained in Table (7) and Figure (5). The test results demonstrate that the concrete specimens without any wastes ( $\mathrm{G} 0 \mathrm{P} 0)$ is high strength concrete according to ACI $363^{[24]}$ that has a compressive strength of 64.7 $\mathrm{N} / \mathrm{mm} 2$ at 60 day age. The compressive strength of concrete containing $15 \%$ of glass powder at 60 day age is higher than reference because of the pozzolanic reaction that occurs between the reactive silica in glass powder and calcium hydroxide produced from the hydration of cement. This reaction produces extra gel that increases the strength at later ages ${ }^{[5]}$. The inclusion of plastic waste coarse aggregate significantly decreases the compressive strength of concrete. It's clear that the percentage reductions in compressive strength for concrete specimens with $25 \%, 50 \%, 75 \%$, and $100 \%$ volumetric replacement of plastic waste coarse aggregate are $25.6 \%, 37.1 \%, 53.2 \%$, and $59.8 \%$ respectively relative to concrete specimens without coarse plastic waste aggregate (G15P0). The reducing in compressive strength is because of the decrease in the bond strength, between the cement paste and HDPE plastic waste aggregate this corresponds with mentioned by Kinda et al. ${ }^{[25]}$. In addition, the natural aggregate is stronger than plastic aggregate, and as the most strength of concrete is from the strength of aggregate because approximately three quarters of the volume of concrete an occupied by aggregate ${ }^{[26]}$, therefore the quantity and the strength of aggregate play an important role in the strength of concrete.
Table 7. Compressive, Splitting, and Flexural Strengths of Concrete Containing Different Percentage of Plastic Waste and $15 \%$ Glass Powder Waste

\begin{tabular}{|c|c|c|c|c|}
\hline $\begin{array}{c}\text { Symbol } \\
\text { of mixes }\end{array}$ & $\begin{array}{c}\text { Content of } \\
\text { plastic waste as } \\
\text { a volumetric } \\
\text { replacement to } \\
\text { natural coarse } \\
\text { aggregate } \\
(\%)\end{array}$ & $\begin{array}{c}\text { Compressive } \\
\text { strength at 6o } \\
\text { day } \\
(\mathrm{MPa})\end{array}$ & $\begin{array}{c}\text { Splitting } \\
\text { tensile } \\
\text { strength } \\
\text { at 60 day } \\
(\mathrm{MPa})\end{array}$ & $\begin{array}{c}\text { Flexural } \\
\text { strength } \\
\text { at 60 day } \\
\text { (MPa) }\end{array}$ \\
\hline G0P0 & --- & 64.7 & 3.97 & 5.68 \\
\hline G15P0 & 0 & 73.3 & 5.41 & 7.65 \\
\hline $\begin{array}{c}\text { G15P2 } \\
5\end{array}$ & 25 & 54.5 & 4.38 & 6.83 \\
\hline $\begin{array}{c}\text { G15P5 } \\
0\end{array}$ & 50 & 46.1 & 3.63 & 5.84 \\
\hline $\begin{array}{c}\text { G15P7 } \\
5\end{array}$ & 75 & 34.3 & 3.19 & 4.92 \\
\hline G15P10 \\
0
\end{tabular}

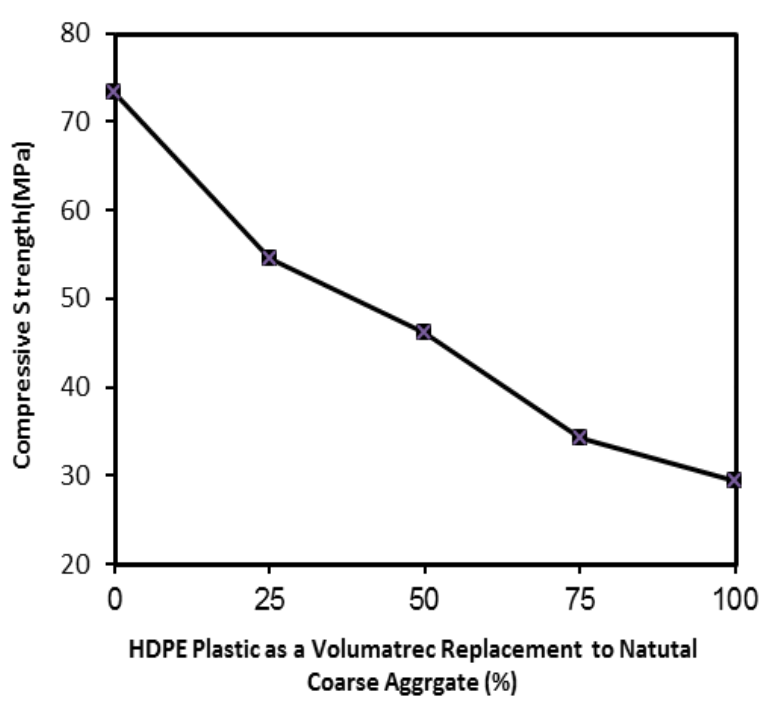

Fig. 5. The effect of plastic waste content on the compressive strength of concrete

4) Splitting tensile strength

The splitting tensile strength values for concrete specimens containing $15 \%$ glass powder waste and different percentages of coarse plastic waste aggregate at 60 day age are presented in Table (7) and Figure (6). It can be observed that there is an increase in splitting tensile strength for concrete containing $15 \%$, glass powder (G15P0) of about $36.3 \%$, compared with the specimens without glass powder (G0P0). This is due to the formation of extra gel from the pozzolanic reaction, in addition the glass powder fills the space between particles and increases the bond between the components of concrete ${ }^{[5,27]}$. Generally, the splitting tensile strength for all concrete samples containing plastic waste aggregate decreases with the increase in plastic content relative to natural crushed coarse aggregate replacement by volume. The percentage decreases in splitting tensile 
strength are $19.0 \%, 32.9 \%, 41.1 \%$, and $43.6 \%$ for specimen containing 25\%, 50\%, 75\%, and $100 \%$ volumetric content of plastic waste aggregate relative to the concrete specimens without plastic aggregate (G15P0). This is due to the lower bonding strength between the surfaces of plastic aggregate and cement paste compared with natural aggregate and cement paste, also natural coarse aggregate is stronger than plastic aggregate, that leads to more compatibility between aggregate and cement paste, then improves the interfacial transition zone between aggregate and cement paste.

\section{5) Flexural strength}

The test results of flexural strength (modulus of rupture) for all concrete specimens are listed in Table (7), and shown in Figure (6). An increase in flexural strength was recorded for concrete containing $15 \%$ glass powder as a partial replacement by weight of cement by about $34.7 \%$ compared with the specimens without glass powder (G0P0). This increase is because glass powder improves the transition zone between aggregate and cement paste consequently due to the pozzolanic reaction, as well as its filling ability to the spaces between particles by extra gel produced from this reactions, therefore the porosity that is inversely proportional to strength is decreased. Generally, the use of plastic waste aggregate as a replacement to natural coarse aggregate in concrete composite leads to a significant decrease in flexural strength for the same reasons mentioned in the compressive and splitting tensile strengths. The percentage reductions are $10.7 \%, 23.7 \%, 35.7 \%$, and $46.3 \%$ for concrete specimens with $25 \%, 50 \%, 75 \%$, and $100 \%$ plastic aggregate respectively relative to concrete specimens without plastic aggregate (G15P0).

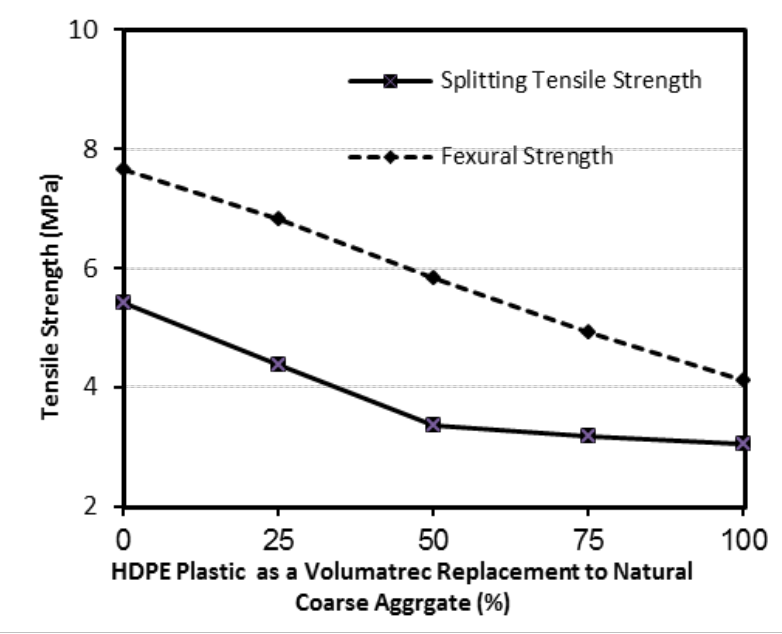

Fig. 6. The effect of plastic waste content on splitting and flexural strength of concrete.

\section{6) Thermal conductivity}

Thermal conductivity results of all concrete specimens at 60 day age are given in Table (VIII). It can be seen that there is a significant decrease in thermal, conductivity factor with the rise in plastic waste aggregate content. This is because the formulation of a large numbers of pores and holes in the texture of concrete in presence of plastic waste aggregate. Also due to porosity that considered main factor that affect the thermal conductivity factor of concrete and the closed pores with air that has low thermal, conductivity factor [28]. Also, plastic waste aggregate has lower thermal conductivity $(0.1175 \mathrm{~W} / \mathrm{m} . \mathrm{K})$ in comparison with natural coarse aggregate $(2 \mathrm{~W} / \mathrm{m} . \mathrm{K})$; this is compatible with Semiha et al. ${ }^{[29]}$.

\section{7) Ultrasonic pulse velocity}

The results of UPV for concrete specimens with and without HDPE plastic are given in Table (8). This nondestructive test is very useful to investigate the homogeneity of concrete containing polymer and plastic waste, i.e. more homogeneity mean increase transmission of velocity through the concrete. The reason of decrease in ultrasonic pulse velocity with the increment in plastic waste is because more nonhomogeneity of concrete with plastic as coarse aggregate as a result of different shapes, low modulus of elasticity, also the plastic is considered very poor for transition wave compared with natural aggregate.

Table 8. Thermal Conductivity and Ultrasonic Pulse Velocity of Concrete Containing Different Percentage of Plastic Waste and $15 \%$ Glass Powder Waste

\begin{tabular}{|c|c|c|c|}
\hline $\begin{array}{c}\text { Symbol of } \\
\text { mixes }\end{array}$ & $\begin{array}{c}\text { Percentage of } \\
\text { plastic waste } \\
\text { as a volumetric } \\
\text { replacement to } \\
\text { natural coarse } \\
\text { aggregate } \\
(\%)\end{array}$ & $\begin{array}{c}\text { Thermal } \\
\text { conductivity } \\
(\mathrm{W} / \mathrm{m} . \mathrm{K})\end{array}$ & $\begin{array}{c}\text { Ultrasonic } \\
\text { pulse } \\
\text { velocity } \\
(\mathrm{km} / \mathrm{sec})\end{array}$ \\
\hline G0P0 & --- & --- & --- \\
\hline G15P0 & 0 & 2.3402 & 5.35 \\
\hline G15P25 & 25 & 2.1699 & 5.03 \\
\hline G15P50 & 50 & 1.6651 & 4.69 \\
\hline G15P75 & 75 & 1.3029 & 4.35 \\
\hline G15P100 & 100 & 1.0663 & 3.82 \\
\hline
\end{tabular}

\section{Conclusions}

From the experiential results and materials used offered in this investigation, the following conclusions can be drawn:

1. The workability of fresh concrete is improved with the use of glass powder or plastic or both; this is important to reduce the water demand of the mixture by increasing workability with the same water cement ratio.

2. There is a decrease in fresh density with the use of $15 \%$ glass powder waste or with the increase in plastic waste aggregate content.

3. There is a significant decrease in oven dry density with the increase in plastic waste aggregate, while there 
is a slight increase when $15 \%$ glass powder waste is only used.

4. The incorporation of $15 \%$ glass powder leads to a decrease in water absorption of concrete. On the other hand the increase in plastic waste content as coarse aggregate in concrete leads to increase in water absorption.

5. The inclusion of $15 \%$ glass powder in concrete improves strength of concrete. While, the inclusion of plastic waste coarse aggregate significantly decreases the compressive strength of concrete. The percentages reduction in compressive strength for concrete samples with $100 \%$ plastic waste coarse aggregate is $59.8 \%$ relative to concrete specimens without any plastic waste coarse aggregate.

6. The inclusion of plastic waste aggregate in side concrete leads to significant decrease in splitting and flexural strengths. The maximum reduction in splitting and flexural strengths is $43.6 \%$ and $46.3 \%$ for concrete specimens with $100 \%$ plastic aggregate respectively.

7. There is a significant reduction in thermal conductivity and ultrasonic pulse velocity with the increase in plastic waste aggregate content.

8. It's possible to produce structural lightweight concrete with good thermal insulation property using 100\% HDPE plastic waste replacement to natural coarse aggregate by volume, e.g. the compressive strength, oven dry density, and thermal conductivity are 29.5 $\mathrm{MPa}, 1862.4 \mathrm{~kg} / \mathrm{m} 3$, and $1.0663 \mathrm{~W} / \mathrm{m} . \mathrm{K}$ respectively.

\section{References}

[1] K., Sobolev, T.R., Naik, Int. Canada, 295-305, (2005).

[2] S.P., Shah, Wang, K., Development and Concrete Technology, China, 15-23, (2004).

[3] D., Jevtic, D., Zakic, A., Savic, Mechanical Testing and Diagnosis J., 1, 22-39, (2012).

[4] Oyenuga, A.A., Bhamidimarri, R., Int. J. of Social Behavioral Educational, 9, 1131- 1137, (2014).

[5] Mehta, P.K., and Monterio, P.J.M., McGraw-Hill Companies, Inc., New York, (2006).

[6] M.C.G. Juenger, R., Siddique, Cement and concrete research J., 78, 71-80, (2015).

[7] A.M., Rashad, J., 41, 303-318, (2013).

[8] Z., Abdul Rahim, Ph.D. Thesis, Jawaharlal Nehru Technological University, Hyderabad, India, (2010).

[9] Instruction Manual, EDX-7000, Shimadzu Corporation, Japan, (2008).
[10] IRAFFINITY-1 Fourier Transform Infrared Spectrophotometer "Manual ", Shimadzu Corporation, Japan, (2008).

[11] ASTM D-792, "Standard Test Methods for Density and Specific Gravity (Relative Density) of Plastics by Displacement", Annual Book of Standards, 0801, (2003).

[12] ASTM D790, "Test Method for Flexural Properties of Unreinforced and Reinforced Plastics and Electrical Insulating Materials", Annual Book of ASTM, 0801, (2003).

[13] ASTM D695, "Standard Test Method for Compressive Properties of Rigid Plastics", Annual Book of ASTM Standards, 0801, (2002).

[14] ASTM D638, "Standard Test Method for Tensile Properties of Plastics", Annual Book of ASTM Standards, 0801, (2010).

[15] Griffin and George:, Griffin and George Ltd., UK. (2002).

[16] European Standard EN ISO 179-1 Standard, "Plastics Determination of Charpy Impact Properties", (2001).

[17] ASTM D3350,"Standard Specification for Polyethylene Plastics Pipe and Fittings Materials", Annual Book of ASTM standards, 0802, (2007).

[18] Building Research Establishment, "Design of Normal Concrete Mixes", London, (1997).

[19] Quick Thermal Conductivity Meter, "Operation Manual, QTM-500", KYOTO Electronics Manufacturing Co., LTD, Japan, (2014).

[20] K.N., Abduel Majid, A.B., Emhemmad, M.B.K., Milad, Int. J. of Chemical and Environmental Eng., 4, 399-402, (2013).

[21] S.C., Kou, G. Poon Lee, W.L., Lai, Waste Management J., 29, 621-628, (2009).

[22] S. Mindess, J.F., Young, D., Darwin, "Concrete", Second Edition, Prentice Hall, U.S.A., 66, (2003).

[23] Neville, A.M., "Properties of Concrete", , Longman Group Ltd., United Kingdom, (2011).

[24] American Concrete Institute Committee ACI 363, "State-of-the-Art Report on High-Strength Concrete", ACI 363R-92, Detroit, (1992).

[25] H., Kinda, S. K., Bernard, W., Prince, Waste Management J., 30, 2312-2320, (2010).

[26] Zongjin, Li, "Advanced Concrete Technology", John Wiley and Sons, Inc., New Jersey, 2011.

[27] Thomas, M., Taylor and Francis Group, London, (2013). 
[28] List of Thermal Conductivities, 2016. Available at: https://en.wikipedia.org/wiki/List_of thermal_conductiv ities.

[29] A., Semiha, A., Kubilay, and C.A., Duran, Composites Part B: Engineering J., 45, 721-726, (2013). 